REVISTA de

PEDAGOGIE

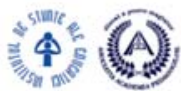

http://revped.ise.ro

Print ISSN 0034-8678; Online ISSN: 2559 - 639X

\title{
AN ANALYSIS OF EDUCATIONAL POLICY MEASURES \\ FOR RURAL EDUCATION
}

\section{O ANALIZĂ A MĂSURILOR DE POLITICI EDUCATIIONALE PROPUSE PENTRU ÎNVĂTĂMÂNTUL RURAL}

\section{Elena UNGUREANU}

\author{
Journal of Pedagogy, 2018 (2), 103 - 126 \\ https://doi.org/10.26755/RevPed/2018.2/103
}

The online version of this article can be found at: http://revped.ise.ro/category/2018-en/

\section{(1) (1)(2)}

This work is licensed under the Creative Commons Attribution-NonCommercial-ShareAlike 4.0 International License.

To view a copy of this license, visit http://creativecommons.org/licenses/by-nc-sa/4.0/ or send a letter to Creative Commons, PO Box 1866, Mountain View, CA 94042, USA.

Published by:

\section{INSTITUTUL DE ȘTIINȚE ALE EDUCAȚIEI}

http://www.ise.ro/

Further information about Revista de Pedagogie - Journal of Pedagogy can be found at:

Editorial Policy: http://revped.ise.ro/editorial-policy/

Author Guidelines: http://revped.ise.ro/the-writer-guide-2/ 


\title{
STUDII EMPIRICE
}

\section{O ANALIZĂ A MĂSURILOR DE POLITICI EDUCA IONALE PROPUSE PENTRU ÎNVĂ ĂMÂNTUL RURAL}

\author{
Elena Ungureanu* \\ Universitatea din Bucureşti, \\ Facultatea de Psihologie şi Ştiin ele Educa iei, \\ Bucureşti, România \\ elena_ungureanu@drd.unibuc.ro
}

\section{Rezumat}

Acest studiu explorează tipologia măsurilor destinate învă ământului rural, propuse în Strategiile Educa ionale, elaborate între anii 2002 - 2017.

Am analizat tematic douăsprezece strategii educa ionale, conform unei grile de analiză ce include obiectivele şi instrumentele propuse spre utilizare în învă ământul din mediul rural. Pe de-o parte, obiectivele identificate au fost organizate tematic, astfel încât să ob inem o hartă a ariilor de interven ie în zona rurală. Pe de altă parte, instrumentele identificate au fost clasificate utilizând tipologia lui Vedung (1998) ca instrumente de reglementare, instrumente economice şi de tip informare.

Ariile de interven ie identificate pe baza obiectivelor au fost: responsabilitatea şcolilor şi parteneriat/ învă area pe tot parcursul vie ii, îmbunătă irea infrastructurii şcolare, calitatea ofertei educa ionale şi şanse egale de acces şi participare. Instrumentele utilizate variază atât în func ie de aria de interven ie, cât şi în func ie de perioada în care sunt propuse spre implementare.

Tendin ele de utilizare identificate în propunerile de instrumente de politici, precum şi eviden ierea ariilor de interven ie privind ruralul, în strategiile de educa ie analizate, reprezintă o modalitate nouă de a conceptualiza evolu ia politicilor publice educa ionale destinate mediului rural. $\mathrm{O}$ în elegere aprofundată asupra planificării strategice şi a propunerilor de utilizare a anumitor instrumente de politici în mediul rural, ar putea contribui la elaborarea şi livrarea unor politici educa ionale tot mai potrivite beneficiarilor.

Cuvinte-cheie: Instrumente de politici, învă are socială, învă ământ rural, paradigma politicilor, politici educa ionale.

* Drd., Universitatea din Bucureşti, Facultatea de Psihologie şi Ştiin ele Educa iei, Bucureşti, România. 


\section{Abstract}

This study explores the typology of rural education policy measures proposed in the Education Strategies developed between 2002 and 2017.

We analyzed twelve strategies, according to an analysis framework that includes the objectives and the instruments proposed for use in relation to problems identified in rural areas. Subsequently, the identified objectives were organized thematically so as to highlight a map of intervention areas in the rural area. Instruments were classified using the Vedung (1998) typology: regulatory, economic and information tools.

The intervention areas identified under the objectives were: school responsibility and partnership/lifelong learning, improved school infrastructure, quality of educational provision and equal opportunities for access and participation. Each field corresponds to certain types of instruments, the use of which varies according to the directions of action as well as the period. For example, in the area of school responsibility and partnership or infrastructure, regulatory or economic instruments are used in particular.

The patterns identified in the policy tool proposals as well as highlighting rural intervention areas in the education strategies analyzed are a new way to conceptualize the evolution of rural public education policies. An in-depth understanding of strategic planning and proposals for the use of certain policy instruments in rural areas could contribute to the development and delivery more appropriate policies, for the targeted population.

Keywords: Educational policy, policy paradigm, policy instruments, rural education, social learning.

\section{Introducere}

Monitorul Educa iei şi Formării din 2017 pune în eviden ă faptul că, în România, ,accesul la educa ia de calitate este o provocare, în special pentru elevii din mediul rural" (Comisia Europeană, 2017). Între mediul urban şi cel rural, unde trăieşte aprox. $45 \%$ din popula ia României, există discrepan e semnificative în ceea ce priveşte cuprinderea copiilor în învă ământul preşcolar, sau în ceea ce priveşte părăsirea timpurie a şcolii. În 2015, rata de părăsire şcolară timpurie a fost de $27,8 \%$ în mediul rural, fa ă de $19,3 \%$ în oraşele şi zonele sub-urbane şi 5,9\% în oraşe mari. În anul 2016, 37,5\% din elevii de clasa a 8-a din şcolile rurale au avut rezultate slabe (sub nota minimă 5) la evaluarea na ională, comparativ cu $15 \%$ în şcolile urbane. De-a lungul timpului aceste problemele au fost abordate de diferite măsuri de politici, 
prin programe şi proiecte educa ionale. În plus, pachetul de strategii educa ionale aflat în vigoare propune o serie de priorită i şi zone de interven ie pentru mediul rural, pe care este necesar să le cartografiem şi să le punem unele în rela ie cu altele, astfel încât să răspundem la întrebarea: în ce măsură problemele învă ământului rural au fost abordate în documentele de politici publice şi ce avem de făcut mai departe?

Analizăm deci măsurile de politici educa ionale, din perspectiva obiectivelor şi instrumentelor propuse pentru învă ământul rural, în perioada 2002 - 2017. Obiectivele şi instrumentele de politici au fost conceptualizate plecând de la perspectiva teoretică a lui Peter Hall (1993). Aceasta are în centrul său conceptul de învă are socială în politicile publice, prin care este eviden iat, totodată, rolul ideilor în schimbarea şi înaintarea politicilor. Prin utilizarea modelului propus de Hall putem discerne un nivel de varia ie mai mare în privin a schimbărilor care au apărut în domeniul învă ământului rural. Totodată, modelul de analiză utilizat ne permite să descriem şi să interpretăm schimbările ce au avut loc de-a lungul timpului în politica educa ională realizată în domeniul învă ământului rural. Articolul este o contribu ie la realizarea unor politici publice care să propună combina ii coerente şi complementare de instrumente într-un design strategic de politici (Cunnigham et al., 2013). Aşadar, scopul analizei este descrierea obiectivelor şi instrumentelor de politici propuse pentru învă ământul rural şi identificarea schimbărilor care au apărut în politica educa ională adresată acestui sector din societatea românească. Am eviden iat şi clasificat: obiectivele în arii de interven ie, instrumentele de politici utilizate în ac iunile destinate învă ământului rural şi nivelul la care sunt aplicate, aşa cum se regăsesc în strategiile de educa ie, ca documente de politici publice. Întrebările analizei noastre sunt: Care sunt ariile de interven ie în politicile pentru învă ământul rural? Care sunt instrumentele utilizate preponderent în politicile educa ionale destinate mediului rural, conform documentelor analizate? Ce fel de schimbări au avut loc în politicile destinate învă ământului rural?

\section{Trecere în revistă a literaturii}

O serie de studii româneşti fac referire la măsuri de politici educa ionale destinate mediului rural. Printre acestea, studiul Institutului de Ştiin e ale Educa iei (ISE) din 2000 coordonat de Mihaela Jigău, Învă ământul rural 
din România, ce îşi propunea să aprofundeze disfunc iile şi problemele învă ământului rural şi cauzele ce stau la baza dezavantajelor manifestate în acest spa iu. Într-o altă analiză, realizată de A. Nedelcu şi E. Palade, în 2006, Educa ia din mediul rural: şcoli inegale, şanse inegale autorii prezintă un inventar al ini iativelor care abordează educa ia în mediul rural şi etapizează primii 15 ani ai tranzi iei în func ie de gradul în care ruralul s-a aflat pe agenda politicilor publice educa ionale. În plus, în 2015, Agen ia Română de Asigurare a Calită ii în Învă ământul Preuniversitar (ARACIP) a publicat un raport privind starea calită ii în unită ile de învă ământ preuniversitar public din mediul rural, în care, printre altele, sunt trecute în revistă principalele programe şi ini iative de politici adresate ruralului.

Credem că literatura românească despre politicile educa ionale ar putea fi îmbogă ită prin utilizarea unui cadru de analiză, care să permită clasificarea instrumentelor utilizate şi în elegerea evolu iei politicilor educa ionale.

În acest sens, am studiat literatura interna ională care propune modalită i de analiză a politicilor pentru a identifica modele potrivite. Am descoperit astfel conceptul de învă are socială în procesul de politici publice. Conceptul are legătură cu încercarea de a în elege care sunt factorii care modelează schimbarea: ce rol are statul în elaborarea politicilor, în compara ie cu al i factori societali? Una dintre perspectivele care a oferit răspunsuri la întrebare este cea statalstructurală. Este o perspectivă care accentuează rolul aparatului statal, dar acordă un rol şi grupurilor de interese, partidelor politice şi altor actori societali. Unul dintre punctele principale ale teoriilor statal-structurale este acela că ,structura şi activită ile anterioare întreprinse de stat afectează natura sau intensitatea cerin elor pe care diverşi actori le articulează" (Hall, 1993, p. 276), forma sub care apare, de fapt, învă area socială.

Unul dintre autorii care abordează conceptul de învă are socială în politicile publice este Peter A. Hall (1993). Acesta defineşte învă area socială în domeniul politicilor ca fiind o încercare deliberată de a ajusta scopurile sau tehnicile unei politici ca răspuns la experien ele din trecut şi la informa iile noi. Al i autori (Moyson, Scholten, \& Weible, 2017) afirmă că învă area în politicile publice poate fi analizată la trei niveluri: nivelul micro (individual), nivelul mezo (nivelul organiza iilor) şi abordările macro (la nivel de sistem). Aceasta din urmă este o analiză care se focalizează pe secven e ale politicilor 
în care deciziile au fost deja luate în institu iile statului şi se regăsesc în documente de politici. Hall (1993) gândeşte procesul politicilor publice, în termeni de învă are şi deci schimbare, referindu-se la trei elemente: scopurile sau obiectivele care ghidează o politică într-un anumit domeniu, tehnicile sau instrumentele utilizate de politică şi nivelul de aplicare al instrumentelor.

Din punctul nostru de vedere, cele trei elemente de analiză propuse de Hall (1993) - obiectivele generale ale politicilor, instrumentele şi nivelul de aplicare al instrumentelor, pot fi utilizate nu doar pentru a în elege gradul de schimbare şi învă are în procesul de politici, ci şi pentru în elegerea priorită ilor şi descrierea ideilor care stau la baza procesului de politici publice. Realizăm astfel primii paşi către creionarea unei paradigme a politicilor (Hall, 1993; Daigneault 2014, 2013; Hogan \& Howlett, 2015). Hogan şi Howlett (2015) subliniază că studiul paradigmelor politicilor publice poate contribui la în elegerea procesului de schimbare a acestora. Daigneault (2015) argumentează că studiul, dezvoltarea şi evolu ia paradigmelor politicilor ar putea permite în elegerea schimbării politice prin în elegerea modului în care factorii idea ionali pot structura sau limita dezbaterea pe marginea politicilor, dar şi ac iunea (Daigneault, 2015). Acelaşi autor (Daigneault 2014, 2013) defineşte paradigma politicilor publice ca fiind un set de idei coerente şi înrădăcinate în rândul celor care dezvoltă politicile, idei capabile de impact asupra con inutului politicilor. Carson (2004, p.28, apud Hogan \& Howlett, 2015 p. 5) consideră că ,o paradigmă a politicilor este un model cognitiv împărtăşit de o anumită comunitate de actori şi care facilitează rezolvarea problemelor".

Putem spune că, definirea politicilor publice ca proces de învă are socială are la bază următoarele asump ii: 1) procesul politicilor este unul incremental; 2) în procesul politicilor publice sunt implica i şi agen i individuali ai schimbării, purtătorii ai ideilor; 3) politicile pot fi analizate evolutiv, în timp, pentru că există influen e ale politicilor trecute, asupra celor din prezent (Heclo, 1974); şi 4) influen ele se datorează şi existen ei unor sisteme de idei sub forma paradigmelor de politici.

\subsection{Cadrul conceptual - obiective şi instrumente de politici}

Cadrul conceptual care ne structurează analiza este construit plecând de la conceptul de politică publică ca un proces de învă are socială (Hall, 1993). 
Acest concept ne-a permis caracterizarea măsurilor de politici în func ie de următoarele elemente: scopurile care ghidează o politică într-un domeniu, instrumentele utilizate şi contextul sau nivelul aplicării acestor instrumente. (Hall, 1993). În plus, am utilizat în scopul în elegerii instrumentelor de politici propuse, clasificarea lui Vedung (1998). Aşadar, analizăm obiectivele existente, instrumentele propuse şi nivelul la care acestea sunt propuse spre implementare. Studiul obiectivelor ne permite identificarea anumitor arii de interven ie în domeniul politicilor pentru învă ământul rural. Totodată, ne va permite să identificăm dacă există schimbări în privin a obiectivelor şi ariilor spre care realizatorii politicilor îşi orientează aten ia.

În privin a instrumentului de politică publică, acesta este în eles ca un ansamblu de idei despre mijloacele cele mai potrivite ale politicilor pentru îndeplinirea obiectivelor. Acestea sunt ,,seturi de tehnici prin care autorită ile guvernamentale îşi exercită puterea în încercarea de a asigura, influen a sau preveni schimbarea socială" (Vedung, 1998, p. 21). În privin a varietă ii instrumentelor, Kooiman consideră că acestea sunt aproape nelimitate şi variază de la instrumente ,,soft”, precum informarea şi recomandarea, până la cele „hard”, precum taxele sau reglementarea. (Kooiman, 2003). Putem spune că în literatura interna ională nu există o clasificare uniformă, general valabilă a instrumentelor de politici publice (Vedung, 1998).

Vom utiliza clasificarea lui Vedung (1998), care propune instrumente de tip reglementator, economice şi de tip informa ie. Reglementările sunt măsurile luate de guvern pentru a influen a oamenii prin reguli şi directive (Vedung, 1998). Conform autorului, caracteristica definitorie este că implică o rela ie de autoritate, ceea ce înseamnă că persoanele sau grupurile vizate de reglementări sunt obligate să se conformeze regulilor respective. Normele, regulamentele, metodologiile sau procedurile pot fi astfel de instrumente. Instrumentele economice implică asigurarea cu resurse materiale, sub formă de bunuri sau bani (Vedung, 1998). Instrumentele de tip economic nu obligă pe cei viza i să beneficieze de stimulentele propuse. Instrumentele de tip informare/informa ie se referă la încercări de influen are a oamenilor prin transferul de cunoaştere, prin comunicare şi persuasiune. Informa iile oferite ar putea viza natura problemei ce se doreşte a fi solu ionată, sau informa ii despre cum oamenii gestionează problema etc. (Vedung, 1998). Ele pot fi sub forma unor campanii de informare, realizarea unor materiale informative care pot fi distribuite, programe de formare, programe de educa ie. 
Hall (1993) propune şi o analiză a nivelului aplicării instrumentelor. Acestea pot fi aplicate la niveluri diferite şi în func ie de anumite praguri sau categorii: vârstă, educa ie, la nivel individual, la nivel organiza ional, sau la un anumit nivel de învă ământ. Ceea ce ne interesează în studiul de fa ă fiind să eviden iem către ce tipuri de beneficiari sunt orientate diversele ac iuni propuse în strategiile educa ionale, în mediul rural.

\section{Metoda utilizată}

Metoda utilizată a fost ceea ce Chelcea (2007) numeşte studiul documentelor sociale scrise oficiale, dar şi analiza tematică a con inutului (Braun \& Clarke, 2008), calitativă. Documentele studiate, douăsprezece strategii na ionale în domeniul educa iei au fost identificate pe paginile de internet ale Ministerului Educa iei $\mathrm{Na}$ ionale (www.edu.ro şi www.oldsite.edu.ro), pe site-ul Guvernului României (www.gov.ro), dar şi pe pagina Camerei Deputa ilor (www.cdep.ro). Căutarea în paginile respective s-a realizat după următoarele cuvinte cheie: strategie educa ie, strategie învă ământ, strategie rural. Documentele identificate sunt elaborate între anii 2002 şi 2017. Anterior acestei perioade, nu exista documente online, pe care noi să le fi identificat. În documentele amintite am eviden iat con inuturile relevante privind: obiectivele şi instrumentele propuse spre utilizare, explicit în rela ie cu aspecte educa ionale legate de învă ământul rural. Unitatea de analiză a fost reprezentată de fiecare document în parte, în care am realizat căutări cu următoarele cuvinte cheie: rural, învă ământ rural, mediu rural, sat. Scopul acestei căutări a fost acela de a identifica acele con inuturi din unită ile de analiză (strategii) care 1) fac referire la mediul rural; şi 2) reprezintă obiective sau scopuri ce au în vedere zona rurală şi 3) reprezintă ac iuni destinate segmentului rural, prin care se propune realizarea obiectivelor.

Con inuturile ob inute, obiective şi măsuri dedicate mediului şi învă ământului rural au fost organizate tematic, astfel:

- obiectivele identificate au fost organizate în arii de interven ie pentru zona rurală;

- ac iunile identificate au fost organizate tematic în tipuri de instrumente utilizând tipologia lui Vedung (1998); 
- ac iunile identificate au fost organizate şi în func ie de nivelul aplicării lor, niveluri pe care le-am creat plecând de la date: beneficiar direct, beneficiar indirect, nivel institu ional local şi nivel institu ional central.

Ariile de interven ie au fost formulate plecând de la problematica obiectivelor identificate în strategii, dar şi utilizând un alt document de politică educa ională: Rapoartele privind starea învă ământului preuniversitar din România, în care sunt enumerate priorită ile şi direc iile de dezvoltare a învă ământului preuniversitar pentru fiecare an (MEN, 2006 - 2016). Astfel poate fi urmărită evolu ia anumitor categorii de obiective şi transformarea altora, cum este de exemplu, cazul ariei pe care ini ial noi am denumit-o ,responsabilitatea şcolilor şi parteneriate cu comunitatea”, iar ulterior a devenit, ,încurajarea învă ării pe tot parcursul vie ii”.

Con inuturile analizate tematic au fost organizate tabelar, fiind realizate mai multe itera ii, pe care, din lipsă de spa iu nu le putem prezenta aici. Am ob inut un total de şapte tabele după cum urmează: a) un tabel care con ine titlul fiecărei strategii, perioada în care a fost elaborată, obiectivele dedicate mediului rural care corespundeau fiecărei strategii şi ac iunile corespunzătoare; b) un tabel care ne-a permis organizarea obiectivelor în arii de interven ie, în care am putut observa că în anumite perioade anumite arii de interven ie au fost prioritizate (tabelul nr. 1); c) un tabel în care am organizat tematic ac iunile dedicate mediului rural, în tipuri de instrumente; d) şi patru tabele în care tipurile de instrumente au putut fi organizate în func ie de aria de interven ie, de perioada elaborării strategiei (tabelul nr. 2) şi de nivelul aplicării (tabelul nr. 3).

Din cele douăsprezece documente cuprinse în analiză, nouă strategii con ineau referiri explicite la învă ământul rural. Totodată, men ionăm că nu am identificat strategii pe paginile de internet men ionate, elaborate în perioada 2010 - 2012. Poate că unul dintre motive este şi acela că Strategia „Educa ie şi Cercetare pentru Societatea Cunoaşterii" a fost realizată pentru perioada 2009 - 2015. Reperul pe care l-am avut atunci când am ordonat cronologic strategiile în cele trei perioade, a fost aderarea la Uniunea Europeană: 2002 2006 - preaderare şi pregătire; 2007 - 2009 - aderare şi acomodare; 2013 - 2017, perioada post-aderare. Strategiile analizate pot fi consultate în sec iunea Referin e. 


\section{Rezultate}

\subsection{Obiectivele - arii de interven ie}

Ariile tematice pe care le-am creat după clasificarea obiectivelor identificate în strategii sunt: responsabilitatea şcolilor şi parteneriat, care ulterior a devenit încurajarea învă ării pe tot parcursul vie ii; îmbunătă irea infrastructurii şcolare; calitatea ofertei educa ionale; şanse egale de acces şi participare. Prezentăm, în continuare, pe scurt, fiecare arie de interven ie. Una dintre dificultă ile pe care le-am întâmpinat în organizarea tematică a obiectivelor a avut legătură cu formulările, uneori vagi, ale obiectivelor prezente în strategii. De exemplu, obiectivul, ,asigurarea şi dezvoltarea unor medii de învă are de calitate care să sprijine procesul de învă are" din Strategia privind modernizarea infrastructurii educa ionale, 2017, putea fi încadrat şi la aria infrastructură. Decizia de a-l încadra la calitate s-a bazat pe faptul că face referire la procesul de educa ie. Astfel, a fost foarte importantă utilizarea unor defini ii pentru fiecare arie. Totodată, obiectivele pentru fiecare arie de interven ie şi distribuirea cronologică, pot fi consultate în Tabelul nr. 1.

Tabelul nr. 1. Organizarea cronologică, pe cele trei perioade, a obiectivelor din strategii

\begin{tabular}{|c|c|c|c|}
\hline \multirow{2}{*}{$\begin{array}{l}\text { Aria de } \\
\text { interven ie }\end{array}$} & \multicolumn{3}{|c|}{ Obiective } \\
\hline & $2002-2006$ & $2007-2009$ & $2013-2017$ \\
\hline $\begin{array}{l}\text { Responsabi- } \\
\text { litatea şcolilor } \\
\text { şi parteneriat/ } \\
\text { învă are pe tot } \\
\text { parcursul } \\
\text { vie ii }\end{array}$ & Nu există & $\begin{array}{l}\text { 1. Îmbunătă irea } \\
\text { eficien ei sistemului } \\
\text { de educa ie prin } \\
\text { introducerea } \\
\text { oportunită ilor } \\
\text { altenative, } \\
\text { comunitare pentru } \\
\text { copiii din zonele } \\
\text { izolate din mediul } \\
\text { rural. }\end{array}$ & $\begin{array}{l}\text { 1. Îmbunată irea orientării } \\
\text { profesionale şi a consilierii în } \\
\text { carieră. } \\
\text { 2. Îmbunătă irea calită ii şi } \\
\text { relevan ei mediilor de învă are } \\
\text { pentru stimularea dezvoltării } \\
\text { competen elor solicitate pe } \\
\text { pia a for ei de muncă sau } \\
\text { fundamentale pentru succesul } \\
\text { în via ă şi în societate. } \\
\text { 3. Consolidarea şi asigurarea } \\
\text { finan ării pentru încurajarea } \\
\text { pie ei de învă are pe tot } \\
\text { parcursul vie ii inclusiv prin } \\
\text { îmbunătă irea serviciilor de } \\
\text { consiliere. } \\
\text { 4. Stimularea dezvoltării } \\
\text { zonelor rurale şi sărace. }\end{array}$ \\
\hline
\end{tabular}




\begin{tabular}{|c|c|c|c|}
\hline \multirow{2}{*}{$\begin{array}{c}\text { Aria de } \\
\text { interven ie }\end{array}$} & \multicolumn{3}{|c|}{ Obiective } \\
\hline & $2002-2006$ & $2007-2009$ & $2013-2017$ \\
\hline $\begin{array}{l}\text { Îmbunătă irea } \\
\text { infrastructurii } \\
\text { şcolare }\end{array}$ & $\begin{array}{l}\text { 1. Asigurarea bazei } \\
\text { materiale a } \\
\text { învă ământului } \\
\text { preuniversitar. } \\
\text { 2. Optimizarea } \\
\text { transportului elevilor } \\
\text { 3. Asigurarea } \\
\text { condi iilor echitabile } \\
\text { de igienă şi educa ie } \\
\text { pentru sănătate în } \\
\text { mediul rural. }\end{array}$ & Nu există. & $\begin{array}{l}\text { 1. Îmbunătă irea condi iilor de } \\
\text { cazare şi posibilită ilor de } \\
\text { transport pentru elevi şi } \\
\text { studen i }\end{array}$ \\
\hline $\begin{array}{c}\text { Calitatea } \\
\text { ofertei } \\
\text { educa ionale }\end{array}$ & $\begin{array}{l}\text { 1. Asigurarea } \\
\text { calită ii proceselor } \\
\text { de predare şi } \\
\text { învă are precum şi a } \\
\text { serviciilor } \\
\text { educa ionale } \\
\text { 2. Oferta } \\
\text { educa ională pe } \\
\text { baza nevoilor de } \\
\text { dezvoltare } \\
\text { personală a elevilor }\end{array}$ & $\mathrm{Nu}$ există. & $\begin{array}{l}\text { 1. Asigurarea şi dezvoltarea unor } \\
\text { medii de învă are de calitate care } \\
\text { să sprijine procesul de învă are. } \\
\text { 2. Îmbunătă irea condi iilor şi a } \\
\text { calită ii programelor Şcoală } \\
\text { după Şcoală (ŞDŞ) oferite } \\
\text { elevilor din grupurile aflate în } \\
\text { situa ie de risc. } \\
\text { 3. Încurajarea stabilită ii pe } \\
\text { post a educatoarelor şi } \\
\text { puericultorilor. }\end{array}$ \\
\hline $\begin{array}{l}\text { Şanse egale de } \\
\text { acces şi } \\
\text { participare }\end{array}$ & $\begin{array}{l}\text { 1. Promovarea } \\
\text { echită ii în educa ie } \\
\text { şi ameliorarea } \\
\text { permanentă a } \\
\text { calită ii învă ării, } \\
\text { astfel încât să fie } \\
\text { respectate } \\
\text { standardele de } \\
\text { performan ă ale } \\
\text { Uniunii Europene şi } \\
\text { OECD. } \\
\text { 2. Creşterea ratei de } \\
\text { participare la } \\
\text { programele } \\
\text { comunitare } \\
\text { a institu iilor } \\
\text { educa ionale din } \\
\text { zonele rurale sau } \\
\text { zonele } \\
\text { dezavantajate . } \\
\text { 3. Asigurarea } \\
\text { egalită ii de şanse şi } \\
\text { sporirea accesului } \\
\text { la educa ie. }\end{array}$ & $\begin{array}{l}\text { 1. Îmbunătă irea } \\
\text { accesului la educa ie } \\
\text { începând cu educa ia } \\
\text { timpurie. } \\
\text { 2. Eliminarea } \\
\text { diferen elor esen iale } \\
\text { dintre învă ământul } \\
\text { rural şi cel urban, } \\
\text { dintre oportunită ile } \\
\text { de învă are oferite } \\
\text { grupurilor } \\
\text { dezavantajate } \\
\text { (grupuri minoritare, } \\
\text { copii cu nevoi } \\
\text { speciale etc.) şi cele } \\
\text { oferite majorită ii. }\end{array}$ & $\begin{array}{l}\text { 1. Creşterea participării şi } \\
\text { facilitarea accesului la } \\
\text { programele de formare } \\
\text { profesională. } \\
\text { 2. Îmbunătă irea accesului la } \\
\text { servicii de educa ie în zonele } \\
\text { insuficient deservite şi în } \\
\text { unită ile de învă ământ } \\
\text { supraaglomerate. } \\
\text { 3. Creşterea capacită ii de } \\
\text { şcolarizare în învă ământul } \\
\text { antepreşcolar. } \\
\text { 4. Creşterea accesului la } \\
\text { îngrijire şi educa ie timpurie a } \\
\text { copiilor. } \\
\text { 5. Asigurarea unei finan ări } \\
\text { adecvate şi eficiente. } \\
\text { 6. Îmbunătă irea sistemului de } \\
\text { acordare a burselor pentru } \\
\text { studen ii din rural. } \\
\text { 7. Încurajarea atragerii } \\
\text { studen ilor din grupuri } \\
\text { subreprezentate sau } \\
\text { netradi ionale, inclusiv a } \\
\text { adul ilor. }\end{array}$ \\
\hline
\end{tabular}




\begin{tabular}{|c|c|c|c|}
\hline \multirow{2}{*}{$\begin{array}{c}\text { Aria de } \\
\text { interven ie }\end{array}$} & \multicolumn{3}{|c|}{ Obiective } \\
\hline & $2002-2006$ & $2007-2009$ & $2013-2017$ \\
\hline $\begin{array}{c}\text { Şanse egale de } \\
\text { acces şi } \\
\text { participare }\end{array}$ & & & $\begin{array}{l}\text { 8. Furnizarea de servicii de } \\
\text { educa ie timpurie } \\
\text { antepreşcolară şi servicii } \\
\text { corespunzătoare unei educa ii } \\
\text { timpurii incluzive, pentru copiii } \\
\text { de la naştere la } 6 \text { ani, îndeosebi } \\
\text { în zonele dezavantajate. } \\
\text { 9. Reducerea decalajului la mai } \\
\text { pu in de } 4 \% \text {, între ratele brute } \\
\text { de înscriere între urban şi rural, } \\
\text { până în } 2020 \text {. }\end{array}$ \\
\hline
\end{tabular}

\subsubsection{Responsabilitatea şcolilor şi parteneriat / Invă are pe tot} parcursul vie ii

Obiectivele pe care am decis să le includem în această arie tematică se referă, în general, la participare şi formare profesională pentru tineri şi adul i. În documentele de politici (MEN, 2006 - 2008) obiectivul ,,responsabilitatea şcolilor şi parteneriat” este orientat către două mari dimensiuni: ,dezvoltarea cadrului normativ şi institu ional privind reorganizarea rolurilor şi a competen elor decizionale şi dezvoltarea parteneriatului educa ional şcoalăinstitu ii guvernamentale / non-guvernamentale, economice, administra ie locală, comunitate în vederea sus inerii procesului educa ional şi a integrării sociale a copiilor şi tinerilor" (MEN, 2008, p. 29). Această arie evoluează mai târziu, din punctul nostru de vedere, în ceea ce putem numi ,încurajarea învă ării pe tot parcursul vie ii”. Legătura dintre cele două este evidentă dacă consultăm documentele europene care stau la baza politicilor din domeniu. De exemplu, în Rezolu ia Consiliului privind un plan european reînnoit pentru învă area în rândul adul ilor (2011), zonele prioritare de interven ie au legătură cu guvernan a (asigurarea coeren ei cu alte zone de politici, relevan ă pentru nevoile societă ii, mediul şi economia, investi iile publice şi private), calitatea, flexibilitatea rutelor şi oferta. Conform analizei noastre, aria devine o prioritate în rela ie cu mediul rural, în strategiile elaborate cu precădere între anii 2013 - 2017 şi într-o singură strategie din intervalul 2007 -2009, dedicată educa iei timpurii.

\subsubsection{Imbunătă irea infrastructurii şcolare}

Consultând Rapoartele privind starea învă ământului preuniversitar (MEN 2006 - 2016), am constatat că până în 2013 obiectivele privind infrastructura 
şcolară sunt formulate, în general, în cadrul altor arii de interven ie, precum acces şi egalitate de şanse. Ulterior putem identifica, în anul 2012 obiectivul „Asigurarea şi modernizarea bazei materiale a învă ământului preuniversitar; utilizarea noilor tehnologii” (MEN; 2012), iar în 2017 subiectului îi este dedicat o întreagă strategie. În analiza realizată de noi, am subsumat acestei arii de interven ie obiective ce îşi propun asigurarea bazei materiale pentru învă ământ sau îmbunătă irea infrastructurii şi re elei şcolare. Nu am inclus acele obiective care au legătură cu procesul de învă ământ. Conform analizei, obiectivele pe care le putem grupa în această tematică sunt regăsite în strategiile elaborate între anii 2002 - 2006 şi 2013 - 2017.

\subsubsection{Calitatea ofertei educa ionale}

Conform Rapoartelor MEN (MEN, 2006 - 2016), asigurarea calită ii învă ământului apare ca obiectiv încă din anul 2006, fiind prezent în fiecare raport până în anul 2016. Obiectivele incluse în această arie se referă la procesul educa ional desfăşurat la clasă şi în şcoală: procesele de predare învă are, programele Şcoală după Şcoală, învă are orientată către elev. În rela ie cu învă ământul din mediul rural, conform analizei noastre, obiectivele privind calitatea învă ământului sunt prezente în strategiile educa iei, în perioada 2002 - 2006 şi 2013 - 2017.

\subsection{4. Şanse egale de acces şi participare}

Această arie de interven ie este una dintre temele de politici educa ionale cele mai prezente în documentele de politici publice româneşti dedicate învă ământului rural, cu obiective explicit definite ce fac referire la egalitatea de şanse şi participarea beneficiarilor direc i la educa ie, la echitate. Obiectivele subsumate acestei arii de interven ie pot fi regăsite în toate strategiile analizate. Acest lucru sugerează importan a, dar şi persisten a problemelor de acces şi egalitate de şanse.

\subsection{Tipul de instrumente utilizate}

În func ie de perioada de elaborare a strategiei, discutăm despre instrumente de reglementare, care, conform Tabelului Nr. 2, au fost propuse în număr 
considerabil mai mare în perioada 2013 - 2017. În această categorie am inclus propunerile ce fac referire la crearea de structuri sau institu ii noi, crearea de standarde şi regulamente sau strategii care să orienteze o anumită activitate. În cazul instrumentelor de tip economic, în perioada 2013 - 2017, numărul acestora se dublează, în compara ie cu perioadele anterioare. În general, instrumentele propuse constau în finan ări pentru infrastructură, dotări şcolare sau servicii sociale de cazare, masă, programe de educa ie timpurie şi burse pentru studiu. Instrumentele de informare, nouă în total, din care cinci propuse în perioada 2002 -2006, nu sunt o op iune frecventă în strategiile analizate. În general, măsurile incluse aici se referă la programe de formare sau perfec ionare şi educa ie pentru beneficiarul direct. În Tabelul nr. 2 pot fi consultate instrumentele pe care le-am identificat în rela ie cu învă ământul rural.

Tabelul nr. 2. Tipurile de instrumente ordonate cronologic

\begin{tabular}{|c|c|c|c|}
\hline $\begin{array}{l}\text { Tipul } \\
\text { instrumentului }\end{array}$ & $2002-2006$ & $2007-2009$ & $2013-2017$ \\
\hline Reglementare & $\begin{array}{l}\text { 1. Continuarea } \\
\text { încadrării cu personal } \\
\text { didactic şi de } \\
\text { conducere calificat. } \\
\text { 2. Crearea şcolilor de } \\
\text { centru în mediul } \\
\text { rural. } \\
\text { 3. Crearea unită ilor } \\
\text { de învă ământ } \\
\text { profesional şi tehnic } \\
\text { de centru în mediul } \\
\text { rural. }\end{array}$ & $\begin{array}{l}\text { 1. Crearea de } \\
\text { instrumente pentru } \\
\text { monitorizarea şi } \\
\text { evaluarea sistemelor } \\
\text { alternative de } \\
\text { educa ie timpurie. }\end{array}$ & $\begin{array}{l}\text { 1. Scheme de mobilitate. } \\
\text { 2. Mix de sprijin financiar şi } \\
\text { tehnic acordat familiilor şi } \\
\text { cadrelor didactice. } \\
\text { 3. Elaborarea şi stabilirea } \\
\text { unor standarde de calitate } \\
\text { pentru programul Şcoala } \\
\text { după Şcoală (ŞDŞ). } \\
\text { 4. Aplicarea, managementul } \\
\text { proiectelor şi liniile } \\
\text { directoare de Management şi } \\
\text { Evaluare (M \& E). } \\
\text { 5. Rute progresive de trecere } \\
\text { de la învă ământul secundar } \\
\text { la învă ământul ter iar. } \\
\text { 6. Consolidarea re elei de } \\
\text { trasee educa ionale. } \\
\text { 7. Elaborarea strategiilor } \\
\text { institu ionale de atragere a } \\
\text { grupurilor sub-reprezentate. } \\
\text { 8. Revizuirea şi crearea unui } \\
\text { cadru normativ al infra- } \\
\text { structurii şcolare propice } \\
\text { unui spa iu de învă are. } \\
\text { 9. Stabilirea unui număr mai } \\
\text { mare de criterii de finan are } \\
\text { pentru institu iile de } \\
\text { învă ământ Superior (IÎS.) }\end{array}$ \\
\hline
\end{tabular}




\begin{tabular}{|c|c|c|c|}
\hline $\begin{array}{l}\text { Tipul } \\
\text { instrumentului }\end{array}$ & $2002-2006$ & $2007-2009$ & $2013-2017$ \\
\hline $\begin{array}{c}\text { Mijloace } \\
\text { economice }\end{array}$ & $\begin{array}{l}\text { 1. Finan are pentru } \\
\text { infrastructură. } \\
\text { 2. Continuarea } \\
\text { procesului de } \\
\text { asigurare a re elei } \\
\text { şcolare cu mijloace } \\
\text { de transport. } \\
\text { 3. Concentrarea } \\
\text { investi iilor în } \\
\text { infrastructură şi în } \\
\text { dotarea unită ilor de } \\
\text { învă ământ din } \\
\text { mediul rural. } \\
\text { 4. Achizi ionarea de } \\
\text { microbuze şcolare. } \\
\text { 5. Dotarea cu grupuri } \\
\text { sanitare complexe. } \\
\text { 6. Asigurarea de } \\
\text { facilită i minime - } \\
\text { alimentarea cu apă, } \\
\text { grupuri sanitare, } \\
\text { instala ii sanitare, } \\
\text { electrice şi de } \\
\text { încălzire prin } \\
\text { Programul pentru } \\
\text { Reabilitatea } \\
\text { Infrastructurii } \\
\text { Şcolare (PRIS) şi } \\
\text { Programul pentru } \\
\text { Învă ământ Rural } \\
\text { (PIR). }\end{array}$ & $\begin{array}{l}\text { 1. Acoperirea } \\
\text { costurilor frecventării } \\
\text { liceului pentru copiii } \\
\text { provenind din mediul } \\
\text { rural sau din grupuri } \\
\text { socioeconomice } \\
\text { dezavantajate. } \\
\text { 2. Sistem de } \\
\text { împrumuturi pentru } \\
\text { studen i cu dobândă } \\
\text { preferen ială pentru } \\
\text { studen ii din rural. } \\
\text { 3. Scutirea cu 75\% de } \\
\text { la plata împrumutului } \\
\text { a absolven ilor care } \\
\text { vor practica profesia } \\
\text { minim } 5 \text { ani în } \\
\text { mediul rural. } \\
\text { 4. Program tip } \\
\text { grădini a de week- } \\
\text { end pentru copiii care } \\
\text { nu pot merge la } \\
\text { grădini ă în cursul } \\
\text { săptămânii. } \\
\text { 5. În zonele rurale } \\
\text { izolate trebuie } \\
\text { concepută şi } \\
\text { dezvoltată o } \\
\text { alternativă a } \\
\text { sistemului de } \\
\text { educa ie de tip } \\
\text { comunitar/familial } \\
\text { şi/sau unită i satelit } \\
\text { ale grădini elor } \\
\text { existente deja. } \\
\text { 6. Centre } \\
\text { multifunc ionale } \\
\text { pentru copii şi } \\
\text { părin i. } \\
\text { 7. Crearea unor locuri } \\
\text { şi spa ii de joacă } \\
\text { comunitare pentru } \\
\text { copiii sub 6 ani. } \\
\text { 8. Facilită i de } \\
\text { transport pentru } \\
\text { copiii care au de } \\
\text { parcurs mai mult de } 1 \\
\text { km până la grădini ă. }\end{array}$ & $\begin{array}{l}\text { 1. Instrumente de finan are } \\
\text { pentru furnizori de formare. } \\
\text { 2. Finan area unor mici pro- } \\
\text { iecte inovatoare ŞDŞ, impli- } \\
\text { când comunitatea, ONG-urile } \\
\text { locale şi asocia iile de } \\
\text { părin i/cadre didactice. } \\
\text { 3. Reabilitarea şi echiparea } \\
\text { grădini elor. } \\
\text { 4. Furnizarea unor stimulente } \\
\text { financiare pentru cadrele didac- } \\
\text { tice debutante din zonele rurale/ } \\
\text { dezavantajate, in primul an de } \\
\text { func ionare. } \\
\text { 5. Stimulente financiare. } \\
\text { 6. Proiectarea unei scheme } \\
\text { de granturi pentru activită ile } \\
\text { remediale şi extracurriculare. } \\
\text { 7. Granturi de recompensare } \\
\text { a IÎS pentru nivelurile } \\
\text { crescute ale înscrierii } \\
\text { studen ilor din mediul rural. } \\
\text { 9. Creşterea numărului de burse } \\
\text { sociale pe bază de nevoi. } \\
\text { 10. Lansarea unui program } \\
\text { de creditare pentru studen i. } \\
\text { 11. Dezvoltarea şi extinderea } \\
\text { re elei de centre de } \\
\text { informare, consiliere şi } \\
\text { orientare profesională. } \\
\text { 12.Dezvoltarea campusurilor } \\
\text { şcolare şi a unor centre de } \\
\text { formare profesională în cadrul } \\
\text { unită ilor de învă ământ } \\
\text { profesional şi tehnic. } \\
\text { 13. Acordarea de sprijin } \\
\text { financiar pentru nevoile de } \\
\text { cazare şi masă ale tinerilor din } \\
\text { mediul rural şi din medii defa- } \\
\text { vorizate înrola i în învă ământul } \\
\text { profesional şi tehnic. } \\
\text { 14. Modernizarea, reabilita- } \\
\text { rea, extinderea spa iilor de } \\
\text { învă are în cadrul unită ilor } \\
\text { de învă ământ cu nivel } \\
\text { primar şi gimnazial şi tehnic. } \\
\text { 15. Dotarea cu microbuze } \\
\text { şcolare şi construirea, reabi- } \\
\text { litarea de campusuri scolare. }\end{array}$ \\
\hline
\end{tabular}




\begin{tabular}{|c|c|c|c|}
\hline $\begin{array}{l}\text { Tipul } \\
\text { instrumentului }\end{array}$ & $2002-2006$ & $2007-2009$ & $2013-2017$ \\
\hline Informare & $\begin{array}{l}\text { 1. Participare la } \\
\text { programele } \\
\text { comunitare Socrates } \\
\text { II şi Leonardo da } \\
\text { Vinci II. } \\
\text { 2. Perfec ionarea şi } \\
\text { evaluarea periodică a } \\
\text { personalului didactic } \\
\text { de predare şi de } \\
\text { conducere prin ac iuni } \\
\text { organizate cât mai } \\
\text { aproape de şcoală. } \\
\text { 3. Îndrumarea şi } \\
\text { consilierea } \\
\text { personalului didactic } \\
\text { şi de conducere din } \\
\text { aceste şcoli prin } \\
\text { activită i specifice } \\
\text { inspec iei şcolare. } \\
\text { 4. Promovarea unor } \\
\text { programe de educa ie } \\
\text { la distan ă pentru elevii } \\
\text { din mediul rural şi } \\
\text { zone defavorizate. } \\
\text { 5. Realizarea unor } \\
\text { cercetări în domeniul } \\
\text { dezvoltării învă ămân- } \\
\text { tului în zonele rurale } \\
\text { din România: politici } \\
\text { și strategii. }\end{array}$ & $\begin{array}{l}\text { 1. O formare } \\
\text { adecvată trebuie } \\
\text { furnizată celor care se } \\
\text { vor ocupa de educa ia } \\
\text { acestor copii în acest } \\
\text { gen de institu ii. } \\
\text { 2. Ini ierea unui } \\
\text { program tip „Mamele } \\
\text { informează Mame” }\end{array}$ & $\begin{array}{l}\text { 1. Introducerea de stagii } \\
\text { scurte de formare, la locul de } \\
\text { muncă şi într-un sistem de } \\
\text { mentorat colegial, pentru } \\
\text { cadrele didactice din } \\
\text { comunită ile } \\
\text { dezavantajate/izolate. } \\
\text { 2. Elaborarea unui manual } \\
\text { pentru utilizatori pentru a } \\
\text { facilita punerea imediată în } \\
\text { aplicare (a programului } \\
\text { ŞDŞ). }\end{array}$ \\
\hline
\end{tabular}

\subsection{Nivelul aplicării instrumentelor}

În privin a nivelului de aplicare a instrumentelor am dedus, în urma analizei, următoarele categorii cărora instrumentele li se aplică: beneficiarul direct, măsurile destinate direct copilului, tânărului sau adultului; beneficiarul indirect, unde am inclus părin ii şi cadrele didactice; nivelul institu ional central măsurile orientate către institu iile centrale ale sistemului, precum Ministerul Educa iei, Institutul de Ştiin e ale Educa iei, universită ile şi nivelul institu ional local, unde am inclus şcolile sau inspectoratele.

În Tabelul nr. 3 regăsim toate instrumentele identificate în rela ie cu învă ământul rural, grupate după beneficiar şi perioada în care a fost elaborată strategia care le con ine. 
Tabelul Nr. 3. Nivelul aplicării instrumentelor de politici

\begin{tabular}{|c|c|c|c|}
\hline $\begin{array}{l}\text { Nivelul } \\
\text { aplicării }\end{array}$ & $2001-2006$ & $2007-2009$ & $2013-2017$ \\
\hline $\begin{array}{c}\text { Beneficiar } \\
\text { direct }\end{array}$ & $\begin{array}{l}\text { 1. Promovarea } \\
\text { unor programe de } \\
\text { educa ie la distan ă } \\
\text { pentru elevii din } \\
\text { mediul rural şi } \\
\text { zone defavorizate. }\end{array}$ & $\begin{array}{l}\text { 1. Acoperirea costurilor frecventării } \\
\text { liceului pentru copiii provenind din } \\
\text { mediul rural sau din grupuri } \\
\text { socioeconomice dezavantajate. } \\
\text { 2. Sistem de împrumuturi pentru } \\
\text { studen i cu dobândă preferen ială } \\
\text { pentru studen ii din rural. } \\
\text { 3. Scutirea cu } 75 \% \text { de la plata împru- } \\
\text { mutului a absolven ilor care vor practica } \\
\text { profesia minim } 5 \text { ani în mediul rural. } \\
\text { 4. Program tip grădini a de week-end } \\
\text { pentru copiii care nu pot merge la } \\
\text { grădini ă în cursul săptămânii. } \\
\text { 5. În zonele rurale, izolate trebuie } \\
\text { concepută şi dezvoltată o alternativă a } \\
\text { sistemului de educa ie de tip } \\
\text { comunitar/familial şi/sau unită i satelit } \\
\text { ale grădini elor existente deja. } \\
\text { 6. Crearea unor locuri şi spa ii de joacă } \\
\text { comunitare pentru copiii sub } 6 \text { ani. } \\
\text { 7. Centre multifunc ionale pentru copii } \\
\text { şi părin i. } \\
\text { 8. Facilită i de transport pentru copiii } \\
\text { care au de parcurs mai mult de } 1 \text { km } \\
\text { până la grădini ă. }\end{array}$ & $\begin{array}{l}\text { 1. Creşterea numărului de } \\
\text { burse sociale pe bază de } \\
\text { nevoi. } \\
\text { 2. Lansarea unui program de } \\
\text { creditare pentru studen i. } \\
\text { 3. Acordarea de sprijin } \\
\text { financiar pentru nevoile de } \\
\text { cazare şi masă ale tinerilor, } \\
\text { din mediul rural şi din medii } \\
\text { defavorizate înrola i în } \\
\text { învă ământul profesional şi } \\
\text { tehnic. }\end{array}$ \\
\hline $\begin{array}{c}\text { Beneficiar } \\
\text { indirect }\end{array}$ & $\begin{array}{l}\text { 1. Participare la } \\
\text { programele } \\
\text { comunitare } \\
\text { Socrates II şi } \\
\text { Leonardo da Vinci } \\
\text { II. } \\
\text { 2. Îndrumarea şi } \\
\text { consilierea } \\
\text { personalului } \\
\text { didactic şi de } \\
\text { conducere din } \\
\text { aceste şcoli prin } \\
\text { activită i specifice } \\
\text { inspec iei şcolare. }\end{array}$ & $\begin{array}{l}\text { 1. O formare furnizată celor care se vor } \\
\text { ocupa de educa ia acestor copii în acest } \\
\text { gen de institu ii. } \\
\text { 2. Ini ierea unui program tip „Mamele } \\
\text { informează Mame” }\end{array}$ & $\begin{array}{l}\text { 1. Scheme de mobilitate } \\
\text { pentru profesori. } \\
\text { 2. Mix de sprijin financiar şi } \\
\text { tehnic acordat familiilor şi } \\
\text { cadrelor didactice, pentru } \\
\text { eliminarea obstacolelor în } \\
\text { calea unui acces mai ridicat la } \\
\text { un învă ământ de calitate. } \\
\text { 3. Introducerea de stagii } \\
\text { scurte de formare, la locul de } \\
\text { muncă şi într-un sistem de } \\
\text { mentorat colegial, pentru } \\
\text { cadrele didactice din comuni- } \\
\text { tă ile dezavantajate/ izolate. } \\
\text { 4. Elaborarea unui manual } \\
\text { pentru utilizatori pentru a } \\
\text { facilita punerea imediată în } \\
\text { aplicare (a programului ŞDŞ). } \\
\text { 5. Finan area unor mici pro- } \\
\text { iecte inovatoare ŞDŞ, impli- } \\
\text { când comunitatea, ONG-urile } \\
\text { locale şi asocia iile de } \\
\text { părin i/cadre didactice. } \\
\text { 6. Furnizarea unor stimulente } \\
\text { financiare pentru cadrele } \\
\text { didactice debutante din } \\
\text { zonele rurale/dezavantajate, } \\
\text { in primul an de func ionare. } \\
\text { 7. Stimulente financiare. } \\
\text { 8. Proiectarea unei scheme de } \\
\text { granturi pentru activită ile } \\
\text { remediale şi extracurriculare. }\end{array}$ \\
\hline
\end{tabular}




\begin{tabular}{|c|c|c|c|}
\hline $\begin{array}{l}\text { Nivelul } \\
\text { aplicării }\end{array}$ & $2001-2006$ & $2007-2009$ & $2013-2017$ \\
\hline $\begin{array}{l}\text { Institu ional } \\
\text { central }\end{array}$ & $\begin{array}{l}\text { 1. Realizarea unor } \\
\text { cercetări în } \\
\text { domeniul dezvol- } \\
\text { tării învă ământului } \\
\text { în zonele rurale din } \\
\text { România: politici } \\
\text { şi strategii. }\end{array}$ & & $\begin{array}{l}\text { 1. Granturi de recompensare a } \\
\text { IÎS pentru nivelurile crescute } \\
\text { ale înscrierii studen ilor din } \\
\text { mediul rural. } \\
\text { 2. Stabilirea unui număr mai } \\
\text { mare de criterii de finan are a } \\
\text { Î́S. }\end{array}$ \\
\hline $\begin{array}{l}\text { Institu ional } \\
\text { local }\end{array}$ & $\begin{array}{l}\text { 1. Perfec ionarea şi } \\
\text { evaluarea periodică } \\
\text { a personalului } \\
\text { didactic de predare } \\
\text { şi de conducere } \\
\text { prin ac iuni } \\
\text { organizate cât mai } \\
\text { aproape de şcoală. } \\
\text { 2. Continuarea } \\
\text { încadrării cu } \\
\text { personal didactic şi } \\
\text { de conducere } \\
\text { calificat. } \\
\text { 3. Crearea şcolilor } \\
\text { de centru în mediul } \\
\text { rural. } \\
\text { 4. Crearea unită- } \\
\text { ilor de învă ământ } \\
\text { profesional şi tehnic } \\
\text { de centru în mediul } \\
\text { rural. } \\
\text { 5. Finan are pentru } \\
\text { infrastructură } \\
\text { 6. Continuarea } \\
\text { procesului de } \\
\text { asigurare a re elei } \\
\text { şcolare cu mijloace } \\
\text { de transport. } \\
\text { 7. Concentrarea } \\
\text { investi iilor în } \\
\text { infrastructură şi în } \\
\text { dotarea unită ilor } \\
\text { de învă ământ din } \\
\text { mediul rural. } \\
\text { 8. Achizi ionarea } \\
\text { de microbuze } \\
\text { şcolare. } \\
\text { 9. Dotarea cu } \\
\text { grupuri sanitare } \\
\text { complexe. } \\
\text { 10. Asigurarea de } \\
\text { facilită i minime - } \\
\text { alimentarea cu apă, } \\
\text { grupuri sanitare, } \\
\text { instala ii sanitare, } \\
\text { electrice şi de } \\
\text { incălzire prin PRIS } \\
\text { şi PIR. }\end{array}$ & $\begin{array}{l}\text { 1. Crearea de instrumente pentru } \\
\text { monitorizarea şi evaluarea sistemelor } \\
\text { alternative de educa ie timpurie. }\end{array}$ & $\begin{array}{l}\text { 1. Instrumente de finan are } \\
\text { pentru furnizorii de formare. } \\
\text { 2. Elaborarea şi stabilirea } \\
\text { unor standarde de calitate } \\
\text { pentru programele programul } \\
\text { ŞDŞ. } \\
\text { 3. Aplicarea, managementul } \\
\text { proiectelor şi liniile directoare } \\
\text { de management \& evaluare. } \\
\text { 4. Reabilitarea şi echiparea } \\
\text { grădini elor. } \\
\text { 5. Rute progresive de trecere } \\
\text { de la învă ământul secundar } \\
\text { la învă ământul ter iar. } \\
\text { 6. Consolidarea re elei de } \\
\text { trasee educa ionale. } \\
\text { 7. Elaborarea strategiilor } \\
\text { institu ionale de atragere a } \\
\text { grupurilor sub-reprezentate. } \\
\text { 8. Revizuirea şi crearea unui } \\
\text { cadru normativ al } \\
\text { infrastructurii şcolare propice } \\
\text { unui spa iu de învă are. } \\
\text { 9. Dezvoltarea şi extinderea } \\
\text { re elei de centre de informare, } \\
\text { consiliere şi orientare } \\
\text { profesională. } \\
\text { 10. Dezvoltarea campusurilor } \\
\text { şcolare şi a unor centre de } \\
\text { formare profesională în } \\
\text { cadrul unită ilor de } \\
\text { învă ământ profesional şi } \\
\text { tehnic. } \\
\text { 11. Modernizarea, } \\
\text { reabilitarea, extinderea } \\
\text { spa iilor de învă are în cadrul } \\
\text { unită ilor de învă ământ cu } \\
\text { nivel primar şi gimnazial şi } \\
\text { tehnic. } \\
\text { 12. Dotarea cu microbuze } \\
\text { şcolare şi construirea, } \\
\text { reabilitarea de campusuri } \\
\text { şcolare. }\end{array}$ \\
\hline
\end{tabular}


O altă analiză, utilă pentru ob inerea unei imagini cât mai complete asupra politicilor adoptate în domeniul învă ământului rural, eviden iază nivelul la care este aplicat instrumentul şi tipul de instrument utilizat. De exemplu, dintre cele trei tipuri de instrumente propuse, beneficiarul direct este abordat, preponderent, $\mathrm{cu}$ instrumente economice, caz valabil şi pentru nivelul institu ional local. Instrumentele propuse cel mai frecvent sunt cele economice, 28 în total, din care 14 la nivel institu ional local, 10 la nivelul beneficiarului direct şi 4 la nivelul beneficiarului indirect. În rest, 13 sunt de reglementare şi 9 de informare, din care 5 în perioada 2002 - 2006.

\section{Discu ii pe marginea rezultatelor analizei de politici}

Scopul acestei analize a fost să descriem obiectivele şi instrumentele de politici propuse pentru învă ământul rural şi să încercăm să identificăm schimbări care au apărut în politica educa ională adresată acestui sector din societatea românească. Întrebările analizei noastre sunt: Care sunt ariile vizate în politicile destinate mediului rural în documentele analizate? Care sunt instrumentele utilizate în politicile educa ionale destinate mediului rural, conform documentelor analizate? Au avut loc schimbări în politicile destinate învă ământului rural? Vom interpreta în continuare rezultatele prezentate în sec iunea anterioară. Ca o imagine de ansamblu, învă ământul rural este abordat de strategiile analizate prin referire la următoarele arii de interven ie: şanse egale de acces şi participare (în toate strategiile), calitatea educa iei şi infrastructură (perioadele 2002 - 2006 şi 2013 - 2017) şi responsabilitatea şcolii fa ă de comunitate şi învă are pe tot parcursul vie ii (2007 - 2009 şi 2013 - 2017). Instrumentele cel mai frecvent propuse pentru învă ământul rural sunt cele de tip economic, 28 la număr, 14 aplicate la nivel institu ional local şi 10 la nivelul beneficiarului direct şi 4 la nivelul beneficiarului indirect. În documentele analizate am identificat 13 instrumente de tip reglementare, dedicate mediului rural. Cel mai pu in utilizate instrumente sunt cele de tip informare, 9, dintre care 5 au fost propuse în perioada $2002-2006$.

În privin a obiectivelor, una dintre modificările pe care le-am sesizat este accentul pus, începând cu perioada 2007, pe obiective din aria responsabilitatea şcolii fa ă de comunitate/învă area pe tot parcursul vie ii, în mediul rural. Putem spune că, cel pu in la nivel ideatic, după 2007, în documentele analizate, apare un interes şi fa ă de legătura dintre şcoală şi comunitate, parteneriatul 
dintre mediul şcolar şi mediul profesional, ca una dintre modalită ile prin care problemele din spa iul rural să fie rezolvate, punându-se în valoare resursele şi specificul local comunitar. Obiective din aceasta arie, lipsesc din strategiile educa ionale elaborate în perioada 2002 - 2006 care se concentrează după cum am spus, în primul rând pe şanse egale de acces şi participare, infrastructură şcolară şi apoi calitatea ofertei educa ionale. Această schimbare în obiectivele propuse are cu siguran ă un corespondent în modul în care problemele de politici şi sursa acestor problemele sunt definite, un aspect ce poate fi abordat într-o cercetare viitoare. În privin a tipologiei instrumentare de politici, observăm scăderea numărului de instrumente de informare şi păstrarea tendin ei de a utiliza preponderent instrumente de tip economic, dar şi de reglementare. Schimbări notabile apar în privin a nivelului de aplicare a instrumentelor, de la o perioadă la alta. In 2002 - 2006 sunt propuse investi ii la nivel local, programe de formare a profesorilor şi măsuri de reglementare prin care să fie sprijinită importan a şcolii de centru, la nivelul localită ilor rurale. Obiectivele şi solu iile propuse ne oferă o imagine echilibrată în privin a naturii şi originii problemelor: sunt propuse atât măsuri economice, cât şi de informare ce vizează mai ales beneficiarul indirect - profesorul - şi nivelul institu ional local. Strategiile 2007 - 2009 aduc o schimbare prin preponderen a instrumentelor economice orientate către beneficiarul direct şi două instrumente de tip informare, către cadre didactice şi părin i. În strategiile din perioada 2013 - 2017, regăsim măsuri economice şi de tip reglementare, orientate cu precădere către nivelul institu ional local şi beneficiarul indirect, profesorul şi părintele.

\begin{tabular}{|c|c|c|}
\hline $\begin{array}{l}\text { Instr. Economice/ } \\
\text { Informare } \\
\mathbf{2 0 0 2 - 2 0 0 6}\end{array}$ & $\begin{array}{l}\text { Instr. Economice/ } \\
\text { Informare } \\
2007-2009\end{array}$ & $\begin{array}{c}\text { Instr. Economice/ } \\
\text { Reglementare } \\
\mathbf{2 0 1 3 - 2 0 1 7}\end{array}$ \\
\hline $\begin{array}{l}\text { Institu ional local/ } \\
\text { Beneficiar indirect }\end{array}$ & Beneficiar direct & $\begin{array}{l}\text { Institu ional local/ } \\
\text { Beneficiar indirect }\end{array}$ \\
\hline
\end{tabular}

Figura nr. 1. Reprezentare a schimbărilor nivelului de aplicare a instrumentelor 
O altă idee pe care o desprindem din analiza efectuată, este faptul că învă ământul rural, la nivelul beneficiarului direct, este abordat preponderent cu instrumente de tip economic. Acest lucru sugerează o reprezentare asupra factorilor care au avut cea mai mare greutate în explicarea problemelor educa ionale întâmpinate de beneficiarii direc i ai educa iei: sărăcia. Or, în chiar Strategia privind reducerea părăsirii timpurii a şcolii în România, 2015 se arată că, de exemplu, abandonul şcolar este un rezultat al unui complex de factori şi nu doar al sărăciei. Cu toate acestea, instrumentele încearcă să compenseze doar lipsurile materiale ale beneficiarilor direc i sau indirec i. $\mathrm{Nu}$ sunt abordate aspecte identitare şi de percep ie asupra rolului şcolii, prin instrumente complementare, de exemplu, de informare.

În literatura de specialitate, dedicată analizei documentelor de politici, este eviden iată importan a clasificării instrumentelor datorită necesită ii de a le utiliza combinat, astfel încât instrumentele să interac ioneze pentru a-şi modela reciproc eficacitatea. Putem vorbi astfel de instrumente de politici complementare. Modalitatea de realizare a combina iei de instrumente este considerată a fi una dintre problemele cele mai importante în planificarea strategică a politicilor (Vedung, 2015; Cunningham, Edler, Flanagan, \& Larédo, 2013).

Una dintre principalele concluzii ale acestui studiu este necesitatea abordării învă ământului rural cu instrumente elaborate strategic: instrumentele de tip economic gândite complementar cu instrumente de tip informare (programe de educa ie, formare, campanii de conştientizare) prin care sunt create capacită ile şi motivele indivizilor de a utiliza oportunită ile create prin intermediul celorlalte (instrumente). Aici intervine abordarea capabilită ilor pe care o propune Amartya Sen $(1992 ; 1999)$. Acesta men ionează că veniturile şi bogă ia, în sensul lor larg sunt,,scopuri generale şi instrumentale care ne oferă mai multă libertate să ducem vie ile pe care avem motive să le valorizăm.” (Sen, 1999, p.14) Au oamenii în mediul rural libertatea şi motivele să valorizeze vie i în care educa ia ocupă un loc important sau măcar este percepută ca un factor important? Şi, în fond, ce înseamnă pentru un om care trăieşte într-un sat sau o comună aflată la 100 de km de un oraş, să aibă libertatea să ducă via a pe care are motive să o valorizeze? 


\section{Concluzii}

În paginile anterioare am descris şi analizat elemente ale politicilor destinate învă ământului rural, aşa cum apar în strategiile educa ionale elaborate între anii 2002 - 2017. Aspectele abordate ne-au permis să creionăm ariile de interven ie în mediul rural şi tipurile de instrumente propuse cel mai frecvent. Studiul oferă un cadru conceptual de analiză a strategiilor educa ionale, dar şi conturul unei imagini despre măsurile de politici propuse pentru mediul rural, în perioada amintită. Totodată, cadrul de analiză utilizat, ce are la bază conceptele de paradigmă a politicilor şi politici ca învă are socială a lui Hall (1993), poate constitui un model descriptiv şi analitic pentru în elegerea schimbărilor politicilor educa ionale. Hall men ionează că învă area la nivelul politicilor poate avea mai multe forme, în func ie de tipurile de schimbări care apar: schimbări la nivelul obiectivelor, schimbări care apar la nivelul instrumentelor sau schimbări care apar la nivelul şi condi iile de aplicare a instrumentelor. Schimbările radicale, de paradigmă ale politicilor apar atunci când observăm modificări la nivelul obiectivelor şi scopurilor politicilor publice, ceea ce Hall numeşte schimbări de ordinul trei. Cele de ordinul doi şi unu presupun utilizarea unor instrumente diferite sau aplicarea acestora la niveluri diferite. De exemplu, la limită, am putea spune că măsurile de politici dedicate mediului rural au trecut printr-o schimbare de ordinul unu, în perioada 2007 -2009 şi ulterior, în 2013 - 2017, când s-a schimbat nivelul de aplicare al diferitelor instrumente (figura nr. 1). Şi spunem la limită, pentru că, ar trebui să fim pruden i în privin a deducerii unor concluzii privind tipologia schimbărilor din cauza limitelor acestei analize. În primul rând, faptul că am utilizat strategiile educa ionale ceea ce nu ne oferă o imagine despre ceea ce s-a realizat, pus în practică în mediul rural, ci despre ceea ce s-a propus. Cercetări ulterioare vor completa imaginea prin utilizarea unei palete mai largi de documente de politici. În plus, am realizat analiza fără să punem obiectivele şi măsurile dedicate mediului rural în contextul mai larg al politicii educa ionale generale. Nu ştim de exemplu, dacă nu cumva, aceleaşi obiective sau tipuri de instrumente nu ar fi regăsite şi pentru alte segmente ale învă ământului: zona urbană. 


\section{Referin e}

- Bemelmans-Videc, M.L., Rist, R.C., \& Vedung, E. (1998). Carrots, sticks and sermons: Policy instruments and their evaluation. New Jersey, SUA: Transaction Publishers.

- Braun, V., \& Clarke, V. (2006). Using thematic analysis in psychology. Qualitative Research in Psychology. 3(2), 77-10. https://doi.org/10.1191/1478088706qp063oa.

- Chelcea, S. (2007). Metodologia cercetării sociologice. Metode cantitative şi calitative (Edi ia a III-a). Bucureşti, România: Editura Economică.

- Comisia Europeană. (2017). Monitorul Educa iei şi Formării: România. Direc ia Generală Educa ie şi Cultură. Accesat online: https://ec.europa.eu/education/ sites/education/files/monitor2017-ro_ro.pdf.

- Cunningham, P., Edler, J., Flanagan, K., \& Laredo, P. (2013). Innovation policy mix and instrument interaction: a review. National Endowment for Science, Technology and the Arts (NESTA) Working Paper, 13, 20. Accesat online: http://www.innovation-policy.org.uk/share/19_Policy\%20mix_linked.pdf.

- Daigneault, P., M. (2015). Can You Recognize a Paradigm When You See One? Defining and Measuring Paradigm Shift. În Howlett, M., Policy Paradigms in Theory and Practice (pp. 43-61). Hampshire, Marea Britanie: Palgrave Macmillan.

- Daigneault, P.-M. (2014). Reassessing the Concept of Policy Paradigm: Aligning Ontology and Methodology in Policy Studies. Journal of European Public Policy, 21(3), 453-69. https://doi.org/10.1080/13501763.2013.834071.

- Descentralizarea învă ământului preuniversitar 2005: http://oldsite.edu.ro/ index.php/articles/c523/.

- Flanagan, K., Uyarra, E., \& Laranja, M. (2011). Reconceptualising the 'policy mix'for innovation. Research policy, 40(5), 702-713. https://doi.org/10.1016/ j.respol.2011.02.005.

- Hall, P. A. (1993). Policy Paradigms, Social Learning, and the State: The Case of Economic Policymaking in Britain. Comparative Politics, 25(3), 275-96. https:/ /doi.org/10.2307/422246.

- Heclo, H. (1974). Modern social politics in Britain and Sweden. Londra, Marea Britanie: Yale University Press.

- Hogan, J., \& Howlett, M. (2015). Reflections on Our Understanding of Policy Paradigms and Policy. În Howlett, M., Policy Paradigms in Theory and Practice (pp. 3-19). Hampshire, Marea Britanie: Palgrave Macmillan.

- Iosifescu, C.,Ş., (2015). Raport Na ional privind starea calită ii în unită ile de invă ământ preuniversitar public din mediul rural. Bucureşti: Tracus Arte.

- Jigău, M. (coord), Anghel, F., Balica, M., Butucă, A., Fartuşnic, C., Horga, I., \& Voicu, B. (2000). Învă ământul rural din România: condi ii, probleme şi strategii de dezvoltare. Bucureşti: ISE. 
- Kooiman, J. (2003). Governing as governance. Londra, Marea Britanie: Sage.

- Moyson,S., Scholten, P., \& Weible, M., C.(2017). Policy learning and policy change: theorizing their relations from different perspectives, Policy and Society, 36(2), 161-177.

- Nedelcu, A., \& Palade, E. (2006), ,Educa ia în mediul rural: şcoli inegale, şanse inegale”, în Crişan, A. (coord.), ,Patru exerci ii de politică educa ională”, Editura Humanitas, Bucureşti.

- OECD (2016), PISA 2015 Results (Volume I): Excellence and Equity in Education, PISA, OECD Publishing, Paris. https://doi.org/10.1787/9789264266490-en.

- Pachetul de strategii în vigoare: https://www.edu.ro/strategii-condi\%C8\% 9Bionalit\%C4\%83\%C8\%9Bi-ex-ante

o Strategia na ională de învă are pe tot parcursul vie ii $2015-2020$;

o Strategia privind reducerea părăsirii timpurii a şcolii în România, 2015;

o Strategia na ională pentru învă ământ ter iar 2015 - 2020;

o Strategia educa iei şi formării profesionale din România pentru perioada 2016-2020;

o Strategia privind modernizarea infrastructurii educa ionale 2017-2023.

- Rapoarte Anuale Privind Starea Învă ământului preuniversitar, 2006 - 2016, Ministerul Educa iei Na ionale. http://edu.ro/rapoarte-publice-periodice.

- Rezolu ia Consiliului privind un plan european reînnoit pentru învă area în rândul adul ilor (2011), https://eur-lex.europa.eu/legal-content/RO/ALL/ ?uri=CELEX:32011G1220(01).

- Sen, A. (1999). Development as freedom. New York, SUA: Random House.

- Sen, A. (1992). Equality reexamined. New York, SUA: Oxford University Press.

- Strategia Dezvoltării Învă ământului Preuniversitar în perioada 2001 - 2004 reactualizare 2002: http://gov.ro/ro/obiective/strategii-politici-programe/strategiadezvoltarii-invatamantului-preuniversitar-in-perioada-2001-2004-reactualizare2002\&page $=2$.

- Strategia M.Ed.C. pentru perioada 2006 - 2008: http://gov.ro/fisiere/ programe_fisiere/030110-medc-strategie06-08.pdf.

- Strategia ministerului educa iei, cercetării şi tineretului cu privire la reducerea fenomenului de violen ă în unită ile de învă ământ preuniversitar - 2007: http:// oldsite.edu.ro/index.php/articles/8213.

- Strategie privind educa ia timpurie (ET) (ca parte a Strategiei convergente privind dezvoltarea timpurie a copilului) aprox. 2008 - 2009: http://oldsite.edu.ro/ index.php?module $=$ uploads $\&$ func $=$ download $\&$ fileId $=11387$ Strategia ,Educa ie şi Cercetare pentru Societatea Cunoaşterii” 2009 - 2015: http://www.cdep.ro/ pdfs/ModernizareEducatie.pdf.

- Strategia anticorup ie în educa ie, 2013 - 2015: https://www.edu.ro/strategiaanticoruptie. 
The online version of this article can be found at: http://revped.ise.ro/category/2018-en/

\section{(cc) $\mathrm{BY}-\mathrm{NC}-\mathrm{SA}$}

This work is licensed under the Creative Commons Attribution-NonCommercial-ShareAlike 4.0 International License.

To view a copy of this license, visithttp://creativecommons.org/licenses/by-ncsa/4.0/ or send a letter to Creative Commons, $P O$ Box 1866, Mountain View, CA 94042, USA.
Versiunea online a acestui articol poate fi găsită la:http://revped.ise.ro/category/2018-ro/

\section{$( c c ) \longdiv { B Y - N C - S A }$}

Această lucrare este licen iată sub Creative Commons Attribution-NonCommercial-ShareAlike 4.0 International License.

Pentru a vedea o copie a acestei licen e, vizita $i$ http://creativecommons.org/licenses/by-nc-sa/4.0/ sau trimite i o scrisoare către Creative Commons, PO Box 1866, Mountain View, CA 94042, SUA. 